\title{
Do different vertical positions of maxillary central incisors influence smile esthetics perception?
}

\author{
Erica Bretas Cabral Menezes ${ }^{1}$, Marcos Alan Vieira Bittencourt ${ }^{1}$, Andre Wilson Machado ${ }^{1}$
}

DOI: http://dx.doi.org/10.1590/2177-6709.22.2.095-105.oar

Introduction: The purpose of this study was to determine the perception of smile esthetics among orthodontists and layperson, with respect to different maxillary central incisors vertical positions in full-face and close-up smile analyses. Methods: Frontal photographs of the smiles of two adult women were used. Images were altered to create a symmetrical image with the gingival margin levels of the maxillary canines matching the central incisors and a 1.0-mm central-to-lateral incisal step. Later, the images were altered in order to create six different central incisor vertical positions in $0.5-\mathrm{mm}$ increments. The images were randomly assembled in an album, which was given to 114 judges, 57 orthodontists and 57 laypersons, who were asked to evaluate the attractiveness of the images using the visual analog scale. The data collected were statistically analyzed by means of 1-way analysis of variance with the Tukey post-hoc test and the Student $t$ test. Results: The highest rated smiles showed two notable characteristics: a) the central incisor gingival margins matched or were $0.5 \mathrm{~mm}$ below the line of the canine gingival margins and; b) the central-to-lateral incisal step was 1.0 to $1.5 \mathrm{~mm}$. The worst smiles showed two notable characteristics: a) the central incisor gingival margins were $1.0 \mathrm{~mm}$ above or $1.5 \mathrm{~mm}$ below the canine gingival margins and; b) no step between the centrals and laterals or a $2.5-\mathrm{mm}$ step. Conclusion: The vertical position of the maxillary central incisors significantly affected the perception of the smile esthetics, whereas slightly extruded central incisors were more esthetically preferred than intruded.

Keywords: Orthodontics. Dental esthetics. Smile.

Objetivo: o objetivo do presente estudo foi avaliar a percepção da estética do sorriso, entre ortodontistas e leigos, em relação a diferentes posições verticais de incisivos centrais superiores, em análises de face completa e do sorriso aproximado. Métodos: foram utilizadas fotografias frontais de sorrisos de duas mulheres adultas. As imagens foram alteradas para criar uma imagem simétrica, com o nível das margens gengivais dos caninos superiores igual ao dos incisivos centrais e um degrau incisal de 1,0 mm entre central e lateral. Posteriormente, as imagens foram alteradas para criar seis diferentes posições verticais de incisivos centrais, em incrementos de $0,5 \mathrm{~mm}$. As imagens foram montadas aleatoriamente em um álbum, que foi dado a 114 avaliadores (57 ortodontistas e 57 leigos), que foram convidados a avaliar a atratividade das imagens usando uma escala analógica visual. Os dados coletados foram analisados estatisticamente por meio da análise de variância (ANOVA) de um fator com o teste post-hoc de Tukey e o teste $t$ de Student. Resultados: os sorrisos mais bem avaliados apresentaram duas características notáveis: a) as margens gengivais dos incisivos centrais corresponderam ou estavam $0,5 \mathrm{~mm}$ abaixo da linha das margens gengivais dos caninos; b) o degrau incisal entre central e lateral foi de 1,0 a 1,5 mm. Os piores sorrisos mostraram duas características notáveis: a) as margens gengivais dos incisivos centrais estavam 1,0 mm acima ou 1,5 mm abaixo das margens gengivais dos caninos e; b) nenhum degrau entre os centrais e laterais ou um degrau de 2,5 mm. Conclusão: a posição vertical dos incisivos centrais superiores afetou significativamente a percepção da estética do sorriso, ao passo que incisivos centrais ligeiramente extruídos foram mais preferidos esteticamente do que intruídos.

Palavras-chave: Sorriso. Estética dentária. Ortodontia.

${ }^{1}$ Universidade Federal da Bahia, School of Dentistry, Salvador, Bahia, Brazil.

Contact address: Andre Wilson Machado

Av. Araújo Pinho, 62, $7^{\circ}$ andar - Universidade Federal da Bahia, Faculdade de Odontologia, Salvador / BA, Brasil - CEP: 40.110-150 - E-mail: awmachado@gmail.com

» The authors report no commercial, proprietary or financial interest in the products or companies described in this article.
How to cite this article: Menezes EBC, Bittencourt MAV, Machado AW. Do different vertical positions of maxillary central incisors influence smile esthetics perception? Dental Press J Orthod. 2017 Mar-Apr;22(2):95-105. DOI: http://dx.doi.org/10.1590/2177-6709.22.2.095-105.oar

Submitted: September 28, 2016 - Revised and accepted: November 11, 2016

» Patients displayed in this article previously approved the use of their facial and intraoral photographs. 


\section{INTRODUCTION}

In order to accomplish optimal dental esthetic results when treating orthodontic patients, it is of paramount importance for the clinician to follow established esthetic guidelines. For many years, these parameters were only based on authors' opinions rather than on evidence-based literature. ${ }^{1-9}$ These guidelines were biased since the concept of beauty is tied to great subjectivity and is strongly influenced by the opinions of others. ${ }^{10-12}$ For instance, the literature suggests that orthodontists and layperson show different perceptions of smile esthetics when evaluating a variety of orofacial characteristics and that orthodontists are more sensitive in detecting deviations from ideal than the general public. ${ }^{13-18}$

In order to provide more objective guidelines regarding the perception of smile esthetics, numerous studies were performed using digital image manipulation. ${ }^{13-27}$ Characteristics that were better elucidated utilizing this technology include: the smile arc; ${ }^{13,19-22}$ the optimal amount of gingival display; ${ }^{14,15,19,23}$ the ideal amount of buccal corridors; $;^{13,19,20}$ the prominence of dental and gingival asymmetries; ${ }^{14-16,19}$ the influence of maxillary anterior diastemas; ${ }^{15,21,24}$ the impact of midline and long axis deviations, ${ }^{14,16,19}$ and the importance of maxillary incisor size, proportion, and simmetry. ${ }^{17,18,24-27}$

Although a great number of smile esthetics guidelines were published, some vital characteristics have not yet been scientifically validated, such as the ideal vertical positioning of the maxillary central incisors. This aspect plays a paramount role on the overall smile esthetics and it is closely related to the definition of the smile arc. Incisal positioning becomes even more important as we consider that youthful smiles show more maxillary incisors while aged smiles tend to show less. ${ }^{28}$

Although this confirms the importance of the maxillary central incisors in evaluating smile esthetics ${ }^{1-3,5,6,9}$ it also highlights some questions: what is the most attractive vertical position of the maxillary central incisors, taking into account both the gingival contour and the incisal edge? Small vertical modifications on maxillary central incisors modify the perception of smile esthetics? Those questions are of paramount importance because they can ultimately assist the clinician in optimizing smile esthetics during bracket positioning and also during finishing and detailing phases.
According to previous studies, the gingival margins of the central incisors should match the cuspids and should be slightly above the gingival margins of the lateral incisors. ${ }^{1-3,5-8}$ An interesting article ${ }^{29}$ used this reference as a start point and evaluated six different vertical positions of the maxillary central incisors. The authors found that highest rated smiles showed two notable characteristics: the central incisor gingival margins matched the laterals and both were $0.5 \mathrm{~mm}$ below the line of the canine gingival margins; and the central-to-lateral incisal step was $1.5 \mathrm{~mm} .{ }^{29}$ Although this article was the only one found in the literature that addressed this issue, some questions still remains. The authors evaluated the smile in a close-up view and thus, did not take into account a full-face appraisal. Secondly, they used only one White adult female smile and thus, we cannot infer that these results can be extrapolated for Afro-American female patients.

The objective of the present study was to assess the esthetic perceptions of orthodontists and layperson with respect to different vertical positions of maxillary central incisors in full-face and close-up frontal smile analyses of two adult women (one White and one Afro-American). The null hypothesis tested was that different vertical positions are rated as equally attractive by orthodontists and layperson.

\section{MATERIAL AND METHODS}

The study was submitted to the research ethics committee of the Dental School of the Universidade Federal da Bahia (Federal University of Bahia), under report number 46946115.3.0000.5024. All participants in the study signed a form of free and informed consent.

The sample size was determined using a pilot study and the Student unpaired $t$ test with $80 \%$ power, the effect size of 0.90 and a bilateral alpha level of $5 \%$. It was determined that the sample should include at least 57 individuals in each group of examiners.

Full-face and close-up photographs of the frontal smiles of two adult women (one White and one Afro-American), between 20 and 30 years of age, were used. The two women displayed no apparent facial asymmetries and exhibited unworn, unrestored and healthy maxillary anterior teeth. These smiles followed some principles of an ideal smile described in the literature: $:^{5}$ adequate width-to-length 
proportion of the esthetic zone; symmetry between maxillary central incisors; convex smile arc; $1.0-\mathrm{mm}$ gingival display; moderate buccal corridors; gingival lines of the central incisors matching the canines, with the laterals $0.5 \mathrm{~mm}$ below; and $1.0-\mathrm{mm}$ central-to-lateral incisal step.

The selected image was digitally altered using Adobe Photoshop CS3 (Adobe Systems Inc, San Jose, Calif). The photo was manipulated to produce a symmetrical image (left to right) and was then retouched to adjust color, brightness and contrast, as well as remove any discoloration in the lips and skin. The image was then condensed to achieve an image with measurements identical to those on the actual patient. Thus, each millimeter measured on the digital and printed image was equivalent to each millimeter measured clinically on the patient, using the right maxillary central incisor as a reference. Furthermore, following recommendations from previous literature, in the close-up images, a great part of the nose and chin was removed to reduce the number of variables on the images. ${ }^{16,21,25,29}$

After, the gingival line between the central incisors and the canines was used as a reference to extrude or intrude maxillary central incisors in $0.5-\mathrm{mm}$ increments (Tab 1), yielding a total of six images for each woman in a full-face view and six images in a close-up view.

The maxillary limit of the full-face image (Figs 1 and 2) was the region just above the top of the head, and the lower limit was the base of the neck. The maxillary limit of the close-up image of the smile (Figs 3 and 4) was the base of the nose, and the lower limit was above the chin.

The final images were digital files with a resolution of $300 \mathrm{dpi}$. They were professionally printed on standard A3 size format $(29.7 \times 42 \mathrm{~cm})$. Then a photo album was assembled containing all images in random order.
The album was given to 114 judges, 57 orthodontists and 57 layperson with a college education but no dental background. Each rater was given brief information about the study and was asked to evaluate the attractiveness of the images. Along with the album, each judge received a form with 100-mm visual analog scales printed for each image, as in previous studies. ${ }^{10,13-17,21-23,28}$ The scale ranged from "very unattractive" on the far left to "very attractive" at the far right. A line was also printed at the midpoint of each scale to provide a reference line for an average level of attractiveness. All judges marked a point along the scale according to their perception of smile esthetics. The scores were then measured in millimeters by the first author with an electronic digital caliper (Starrett, Suzhou, China).

In order to assess the reliability of the method, twelve raters from each group were randomly selected. They were asked to evaluate one page of the album in which there were two identical images. ${ }^{16,21,25,29}$ Correlation coefficients were used to compare the scores for those images in order to determine intrarater agreement. High levels of reliability were found because all coefficients were greater than or equal to 0.73 , for both group of raters.

Data was submitted to statistical analyses with the software SPSS 16.0 (Statistical Package for Social Sciences; SPSS Inc., Chicago, IL, USA). Descriptive statistics were reported as means and standard deviations. Differences in the mean esthetic scores in the six levels of asymmetries were analyzed by using one-way analysis of variance with the Tukey posthoc test. To compare the distributions of the mean scores between the full-face and close-up images and also between the orthodontists and laypersons, the Student $t$ test was used. The level of significance was established at 5\%.

Table 1 - Characteristics of the smiles used in this study.

\begin{tabular}{llll}
\hline Altered vertical positions & Central gingival margins & Central incisor edges & Amount of gingival display \\
\hline A: $1.0 \mathrm{~mm}$ intruded & $1.0 \mathrm{~mm}$ above the canines & Matching the laterals & $0 \mathrm{~mm}$ \\
\hline B: $0.5 \mathrm{~mm}$ intruded & $0.5 \mathrm{~mm}$ above the canines & $0.5 \mathrm{~mm}$ below the laterals & $0.5 \mathrm{~mm}$ \\
\hline C: $0 \mathrm{~mm}$ (control) & Matching the canines & $1.0 \mathrm{~mm}$ below the laterals & $1.0 \mathrm{~mm}$ \\
\hline D: $0.5 \mathrm{~mm}$ extruded & $0.5 \mathrm{~mm}$ below the canines & $1.5 \mathrm{~mm}$ below the laterals & $1.5 \mathrm{~mm}$ \\
\hline E: $1.0 \mathrm{~mm}$ extruded & $1.0 \mathrm{~mm}$ below the canines & $2.0 \mathrm{~mm}$ below the laterals & $2.0 \mathrm{~mm}$ \\
\hline F: $1.5 \mathrm{~mm}$ extruded & $1.5 \mathrm{~mm}$ below the canines & $2.5 \mathrm{~mm}$ below the laterals & $2.5 \mathrm{~mm}$ \\
\hline
\end{tabular}



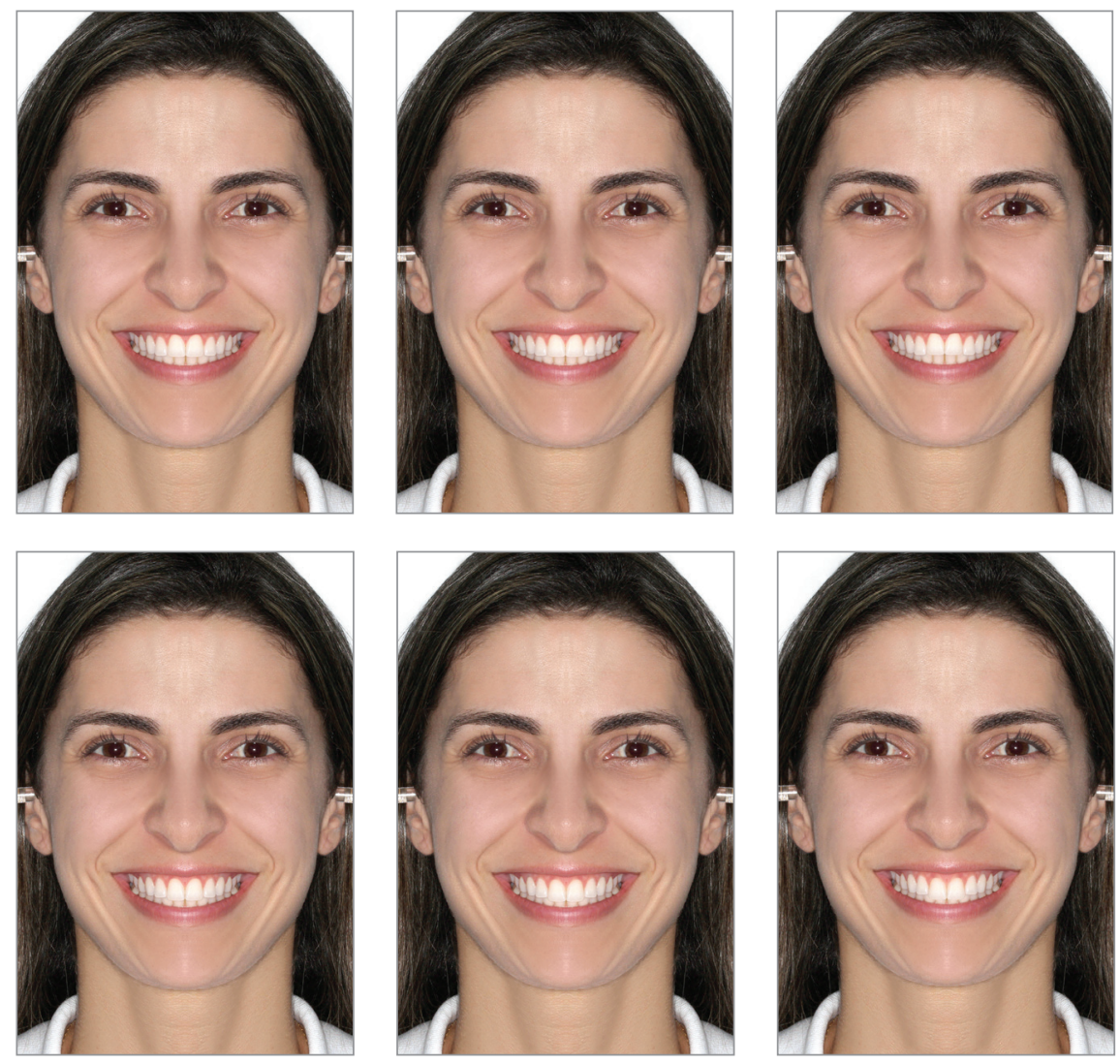

Figure 1 - White woman full-face smile view in $0.5-\mathrm{mm}$ altered vertical positions increments
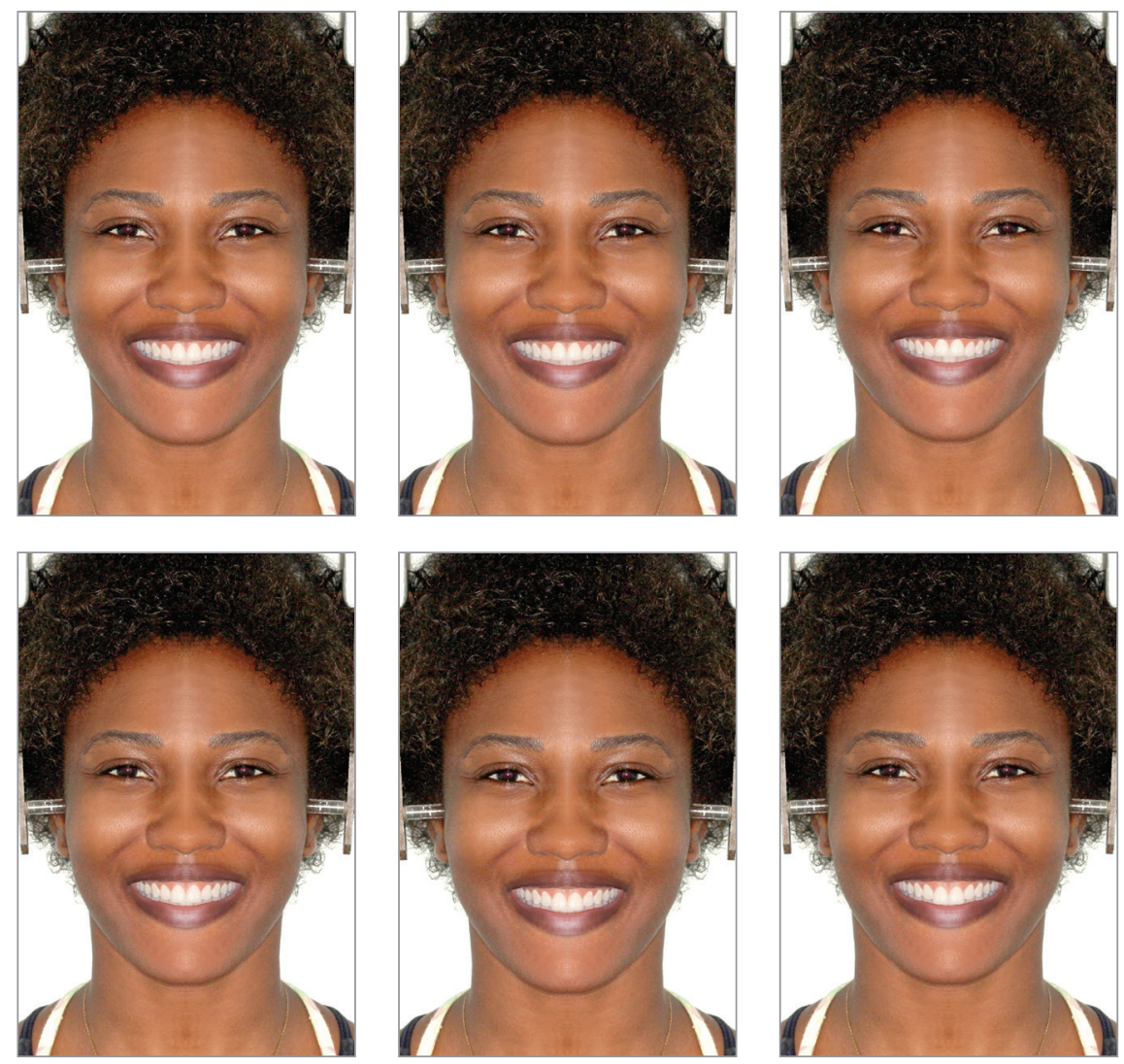

Figure 2 - Afro-American woman full-face smile view in $0.5-\mathrm{mm}$ altered vertical positions increments. 

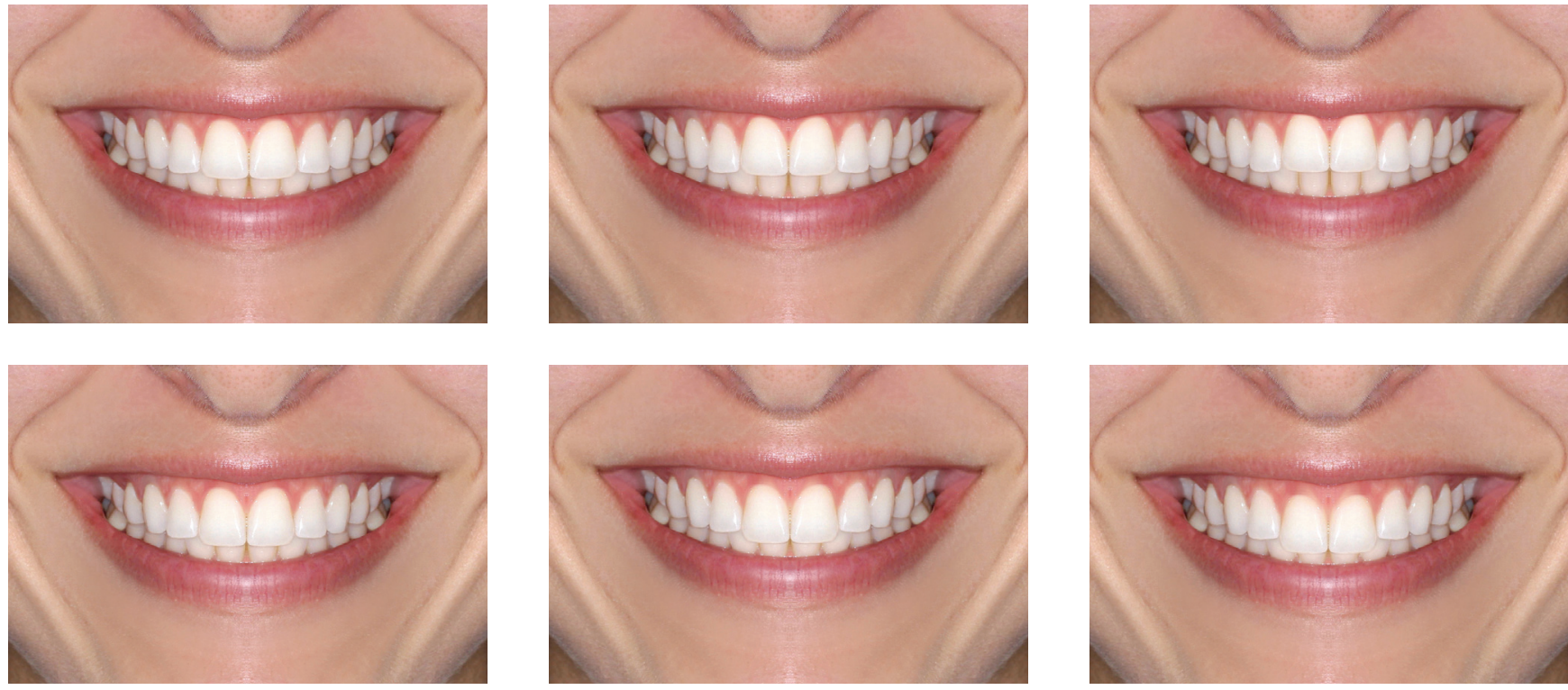

Figure 3 - White woman close-up smile view in 0.5-mm altered vertical positions increments
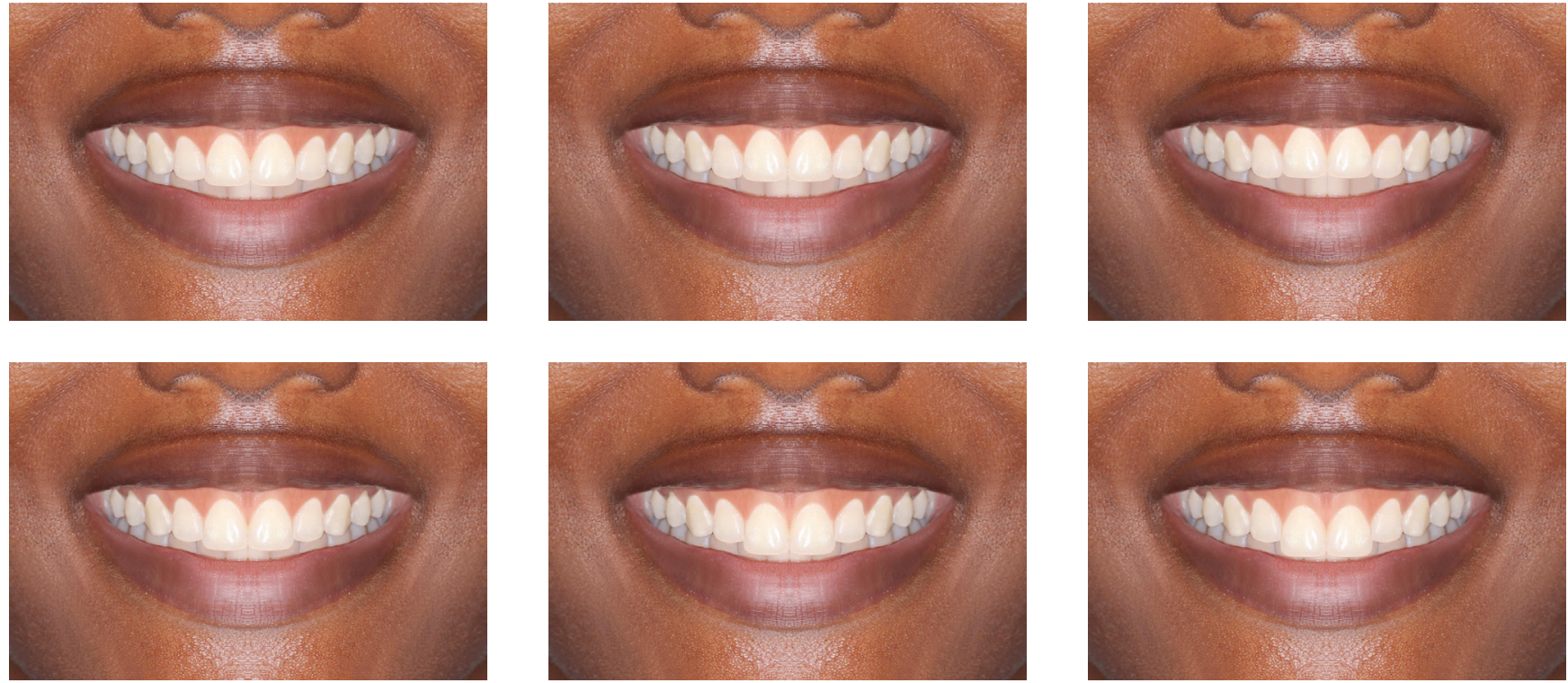

Figure 4 - Afro-American woman close-up smile view in 0.5-mm altered vertical positions increments. 


\section{RESULTS}

When comparing assessments of full-face with close-up views, no statistically significant difference was found $(p>0.05)$ in the majority of the situations (20 out of 24) (Tables 2, 3, 4 and 5). After this result, the closeup view was used as reference to address the results.

In Table 6, in the assessment of the close-up view of the smile for the White woman, according to the orthodontists, the most attractive smiles were those in which the central incisor was $0.5 \mathrm{~mm}$ extruded (mean score 79.6) and the control, unaltered position (mean 72). Orthodontists rated as least attractive the smiles in which the central incisor was $1.0 \mathrm{~mm}$ intruded (mean 26.5) or $1.5 \mathrm{~mm}$ extruded (mean 51). According to layperson, the most attractive smiles were those with the central incisor $0.5 \mathrm{~mm}$ extruded (mean 78), the control (mean 76.6), and the central incisor $1.0 \mathrm{~mm}$ extruded (mean 69.3). The least attractive smiles, ac- cording to layperson, were those in which the central incisor was $1.5 \mathrm{~mm}$ extruded (mean 55.7) and $1.0 \mathrm{~mm}$ intruded (mean 61.4).

When assessing the Afro-American woman, similar results were found. The orthodontists assigned the highest scores to the control (mean 79.5) and to the central incisor $0.5 \mathrm{~mm}$ extruded (mean 71). The least attractive smiles were the $1.5 \mathrm{~mm}$ extruded (26.2) and the $1.0 \mathrm{~mm}$ intruded (38.4). Following the same pattern, layperson assigned the highest scores to the control (73.1), the $0.5 \mathrm{~mm}$ extruded (mean 70.7) and the $1.0 \mathrm{~mm}$ extruded (mean 69.7). The least attractive smiles were those in which the central incisor was $1.5 \mathrm{~mm}$ extruded (mean 46.8 ) and $1.0 \mathrm{~mm}$ intruded (mean 52.6).

The comparison between both groups of raters showed statistical differences in some situations where laypersons were more tolerant, ranking the smiles with higher scores (Tables 6 and 7).

Table 2 - Means and standard deviations of the attractiveness of the images in full-face and close-up views of the smile of White woman for the orthodontists.

\begin{tabular}{|c|c|c|c|c|c|}
\hline \multirow{2}{*}{ Variable } & \multicolumn{2}{|c|}{ Full-face view } & \multicolumn{2}{|c|}{ Close-up view } & \multirow{2}{*}{ p } \\
\hline & Mean & SD & Mean & SD & \\
\hline $1.0 \mathrm{~mm}$ intruded & 41.5 & 28.9 & 36.4 & 26.5 & 0.329 \\
\hline $0.5 \mathrm{~mm}$ intruded & 65.7 & 24 & 57 & 23.4 & 0.054 \\
\hline $0 \mathrm{~mm}$ (control) & 71.4 & 19.9 & 72 & 15.9 & 0.86 \\
\hline $0.5 \mathrm{~mm}$ extruded & 81.6 & 15.9 & 79.6 & 14.9 & 0.489 \\
\hline $1.0 \mathrm{~mm}$ extruded & 75.5 & 17.8 & 64.4 & 20 & $0.002^{\star}$ \\
\hline $1.5 \mathrm{~mm}$ extruded & 53 & 24.1 & 42.8 & 23.7 & $0.025^{*}$ \\
\hline
\end{tabular}

*statistical difference $(p<0.05)$

Table 3 - Means and standard deviations of the attractiveness of the images in full-face and close-up views of the smile of White woman for the laypersons.

\begin{tabular}{|c|c|c|c|c|c|}
\hline \multirow{2}{*}{ Variable } & \multicolumn{2}{|c|}{ Full-face view } & \multicolumn{2}{|c|}{ Close-up view } & \multirow{2}{*}{$p$} \\
\hline & Mean & SD & Mean & SD & \\
\hline $1.0 \mathrm{~mm}$ intruded & 61.3 & 26.7 & 61.4 & 26.9 & 0.564 \\
\hline $0.5 \mathrm{~mm}$ intruded & 67.2 & 17.5 & 67.7 & 19.8 & 0.959 \\
\hline $0 \mathrm{~mm}$ (control) & 76.8 & 17.5 & 76.6 & 15.6 & 0.943 \\
\hline $0.5 \mathrm{~mm}$ extruded & 79 & 17.5 & 78 & 17.9 & 0.778 \\
\hline $1.0 \mathrm{~mm}$ extruded & 74.2 & 21.1 & 69.3 & 23.4 & 0.241 \\
\hline $1.5 \mathrm{~mm}$ extruded & 66.3 & 24.3 & 55.7 & 23.7 & $0.019^{*}$ \\
\hline
\end{tabular}

*statistical difference $(p<0.05)$ 
Table 4 - Means and standard deviations of the attractiveness of the images in full-face and close-up views of the smile of Afro-American woman for the orthodontists.

\begin{tabular}{|c|c|c|c|c|c|}
\hline \multirow{2}{*}{ Variable } & \multicolumn{2}{|c|}{ Full-face view } & \multicolumn{2}{|c|}{ Close-up view } & \multirow{2}{*}{$p$} \\
\hline & Mean & SD & Mean & SD & \\
\hline $1.0 \mathrm{~mm}$ intruded & 38.8 & 25 & 38.4 & 20.6 & 0.927 \\
\hline $0.5 \mathrm{~mm}$ intruded & 54.9 & 22.4 & 44.8 & 20.2 & 0.082 \\
\hline 0 mm (control) & 74.1 & 15.6 & 79.5 & 15 & 0.058 \\
\hline $0.5 \mathrm{~mm}$ extruded & 69.2 & 17.4 & 71 & 14.9 & 0.607 \\
\hline $1.0 \mathrm{~mm}$ extruded & 51.6 & 20.1 & 61.9 & 20.2 & 0.074 \\
\hline $1.5 \mathrm{~mm}$ extruded & 32.8 & 21.8 & 28.2 & 20.8 & 0.252 \\
\hline
\end{tabular}

Table 5 - Means and standard deviations of the attractiveness of the images in full-face and close-up views of the smile of Afro-American woman for the laypersons.

\begin{tabular}{|c|c|c|c|c|c|}
\hline \multirow{2}{*}{ Variable } & \multicolumn{2}{|c|}{ Full-face view } & \multicolumn{2}{|c|}{ Close-up view } & \multirow{2}{*}{$p$} \\
\hline & Mean & SD & Mean & SD & \\
\hline $1.0 \mathrm{~mm}$ intruded & 59.3 & 23.7 & 52.6 & 22.7 & 0.18 \\
\hline $0.5 \mathrm{~mm}$ intruded & 67.5 & 22 & 59.2 & 22.4 & 0.24 \\
\hline $0 \mathrm{~mm}$ (control) & 75.7 & 15.9 & 73.1 & 22.6 & 0.484 \\
\hline $0.5 \mathrm{~mm}$ extruded & 68 & 20.5 & 70.7 & 20.1 & 0.631 \\
\hline $1.0 \mathrm{~mm}$ extruded & 65.8 & 24.9 & 69.7 & 20.5 & $0.003^{*}$ \\
\hline $1.5 \mathrm{~mm}$ extruded & 51.9 & 27.6 & 46.8 & 24.4 & 0.303 \\
\hline
\end{tabular}

*statistical difference $(p<0.05)$.

Table 6 - Means and standard deviations of the attractiveness of the smile of White woman.

\begin{tabular}{|c|c|c|c|c|c|c|c|}
\hline \multirow{2}{*}{ Variable } & \multicolumn{3}{|c|}{ Orthodontists } & \multicolumn{3}{|c|}{ Laypersons } & \multirow{2}{*}{$\begin{array}{l}\text { Orthodontists x } \\
\text { Laypersons }\end{array}$} \\
\hline & Mean & SD & Results* & Mean & SD & Results* & \\
\hline $1.0 \mathrm{~mm}$ intruded & 36.4 & 20.5 & $\mathrm{D}$ & 61.4 & 26.9 & $C, D$ & $* *$ \\
\hline $0.5 \mathrm{~mm}$ intruded & 57 & 23.4 & C & 67.7 & 19.8 & $\mathrm{~B}, \mathrm{C}$ & $\star *$ \\
\hline $0 \mathrm{~mm}$ (control) & 72 & 15.9 & $A, B$ & 76.6 & 15.6 & $A, B$ & \\
\hline $0.5 \mathrm{~mm}$ extruded & 79.6 & 14.9 & A & 78 & 17.9 & A & \\
\hline $1.0 \mathrm{~mm}$ extruded & 64.4 & 20 & $\mathrm{~B}, \mathrm{C}$ & 69.3 & 23.4 & $A, B, C$ & \\
\hline $1.5 \mathrm{~mm}$ extruded & 51 & 23.7 & D & 55.7 & 23.7 & D & \\
\hline
\end{tabular}

*Variables with the same letter do not differ statistically $(p<0.05)$; **statistical difference between groups of examiners $(p<0.05)$

Table 7 - Means and standard deviations of the attractiveness of the smile of Afro-American woman

\begin{tabular}{|c|c|c|c|c|c|c|c|}
\hline \multirow{2}{*}{ Variable } & \multicolumn{3}{|c|}{ Orthodontists } & \multicolumn{3}{|c|}{ Laypersons } & \multirow{2}{*}{$\begin{array}{l}\text { Orthodontists } \mathrm{x} \\
\text { Laypersons }\end{array}$} \\
\hline & Mean & SD & Results* & Mean & SD & Results* & \\
\hline $1.0 \mathrm{~mm}$ intruded & 38.4 & 20.6 & C. D & 52.6 & 22.7 & C, D & $\star *$ \\
\hline $0.5 \mathrm{~mm}$ intruded & 44.8 & 20.2 & C & 59.2 & 22.4 & $B, C$ & \\
\hline $0 \mathrm{~mm}$ (control) & 79.5 & 15 & A & 73.1 & 22.6 & A & \\
\hline $0.5 \mathrm{~mm}$ extruded & 71 & 14.9 & $A, B$ & 70.7 & 20.1 & $A, B$ & \\
\hline $1.0 \mathrm{~mm}$ extruded & 61.9 & 20.2 & B & 69.7 & 20.5 & $A, B$ & $* *$ \\
\hline $1.5 \mathrm{~mm}$ extruded & 28.2 & 20.8 & D & 46.8 & 24.4 & D & $\star *$ \\
\hline
\end{tabular}

*Variables with the same letter do not differ statistically $(p<0.05)$; **statistical difference between groups of examiners $(p<0.05)$ 


\section{DISCUSSION}

The maxillary central incisors are the key determinant in evaluating smile esthetics and thus, their vertical positioning is an aspect of paramount importance. ${ }^{1-3,5,6,9}$ Their vertical placement has implications on different areas such as anterior esthetic restorations; anterior veneer placements; setting of dentures; and orthodontic bracket positioning. ${ }^{29}$

According to a frequently cited guideline, the gingival margins of the central incisors should match the canines, and the gingival margins of the lateral incisors should be slightly below that level. ${ }^{1-3,5-8}$ Although a great number of esthetic treatment plans are based on this clinical recommendation, no evidence based study supporting this guideline could be found. Charruel et $\mathrm{al}{ }^{30}$ evaluated 103 young adults with healthy anterior dentition in order to assess the relationship between the gingival margins of the maxillary centrals, laterals and canines. They did not corroborate the frequently cited recommendation, but rather, found that the ideal position of the central incisor gingival margins is located below the line tangent to the canine's gingival margins. ${ }^{30}$

The methodology to identify what is the ideal vertical positioning of the maxillary centrals is somehow difficult because when the position is altered, one is not only evaluating the design of the gingival margins but also the incisal edges. Some studies have been conducted to evaluate the threshold for the presence of gingival asymmetries between centrals and laterals $^{14-16,19}$ and also to determine the ideal central-tolateral incisal step. ${ }^{19,27}$ However, these studies instead of modifying the centrals vertical position, modified teeth height and thus, they did not account for the fact that altering the gingival margins and incisal edges also alters tooth width-to-length proportions. Ideally, in order to determine the perception of an individual characteristic it is necessary to isolate only that characteristic during the evaluation process. Thus, we followed the same method suggested in the literature ${ }^{29}$ to modify the maxillary centrals vertical position, maintaining the teeth anatomy unaltered. It is clear that with this method when maxillary centrals are intruded, the amount of gingival display is decreased as well as the central-to-lateral incisal step, whereas the opposite will be found when maxillary incisors are extruded.
Analysis of the data from our study showed that maxillary central incisors vertical positioning significantly affected the perception of smile esthetics for both the White and Afro-American smiles. The highest scores were assigned to the control and the $0.5 \mathrm{~mm}$ extruded smiles, for the orthodontists and; the control, $0.5 \mathrm{~mm}$ extruded and the $1.0 \mathrm{~mm}$ extruded smiles, for the layperson, with no statistical difference among them (Tables 6 and 7). Those setups were partially corroborated by Machado et $\mathrm{al},{ }^{29}$ who also found highest scores assigned to the control and the $0.5 \mathrm{~mm}$ extruded smiles. Conversely, we found that the least attractive smiles were the extreme situations $(1.0 \mathrm{~mm}$ intruded and $1.5 \mathrm{~mm}$ extruded smiles, with no statistical difference among them) for both groups of raters.

From a clinical standpoint, it is important to evaluate both the gingival margins and the centralto-lateral incisor step whenever modifying the maxillary centrals vertical position. The most attractive smiles exhibited the following clinical characteristics: (a) central incisors gingival margins matching the canines or $0.5-1.0 \mathrm{~mm}$ below that line and; (b) central-to-lateral incisal steps of 1.0-2.0 $\mathrm{mm}$. When the gingival margins are considered, those smiles presented with a 1.5 to $2.0-\mathrm{mm}$ gingival display in the central incisor area, which is within the normal esthetic limits according to the literate. ${ }^{14,15,23}$ In other words, when slightly extruding maxillary centrals one may increase the amount of gingival display but still optimizing overall smile esthetics. When the central-to-lateral incisal steps are considered, it is evident that greater steps $(1.0-2.0 \mathrm{~mm})$ were preferred than small ones. The preference for greater steps between centrals and laterals is confirmed by Machado et $\mathrm{al}^{29}$ and Ker et al,${ }^{19}$ who found the ideal step to be $1.5 \mathrm{~mm}$ and $1.4 \mathrm{~mm}$, respectively. On the other hand, King et $\mathrm{al}^{27}$ found that the most attractive central-to-lateral incisal step was $0.6 \mathrm{~mm}$. Given the great variability in perception of this variable, communication with the patient is essential during the treatment planning process.

This dual analysis of the role of gingival margins and incisal edges in the overall perception of smile esthetics has a profound impact on clinical decisionmaking. According to a recent article, ${ }^{29}$ gingival margins have a weak correlation with overall per- 
ception of smile esthetics, while incisal edges have a strong correlation with the smile esthetics analysis. Ultimately, the contour of the incisal edges is the single most important variable in perception of smile esthetics. ${ }^{15}$

With this in mind, when deciding upon the ideal vertical position of the maxillary central incisors in a given case, the clinician should give more priority to proper positioning of the incisal edges instead of gingival margins or amount of gingival display (unless it is within the threshold: $0-3.0 \mathrm{~mm}$ ). Based on the data of the present and previous studies, ${ }^{14-16,19}$ orthodontists and layperson are more tolerant to gingival asymmetries than incisal edge discrepancies. ${ }^{25}$ Thus, since the threshold for gingival asymmetry and also for amount of gingival display are large, it makes more sense to emphasize on an ideal centralto-lateral incisal step. ${ }^{29}$

If an orthodontist strictly follows the guideline suggesting that the central incisor gingival margins should match the canines, one may create a smile in which the maxillary central incisor edges are above those of the canines, creating a flat, reverse or nonconsonant smile..$^{5,8,13,20}$ On the other hand, if proper vertical position of the maxillary centrals is achieved with emphasis on the incisal edges being located below the tips of the canines, a convex, or consonant, smile is achieved. ${ }^{2}$ Clinically, the position of the incisal edges should follow the lower lip ${ }^{1-3,6}$ and thus, this aspect needs to be evaluated to assist in the placement of the maxillary central incisor edges.

During bracket placement small differences in the position of the maxillary central incisors can have a great impact on smile esthetics. Interestingly, if we use the same bracket height for centrals and canines and consider that they have the same anatomical crown length, after proper aligning and leveling phases, their gingival margins will be even. According to our results, if centrals margins matches the canine's margins or are $0.5-1.0 \mathrm{~mm}$ below, the smile is perceived to be very attractive. However, if central incisor gingival margins are even slightly above the canines $(0.5-1.0 \mathrm{~mm})$ the smile is considered extremely unattractive. Ultimately, clinicians must take care in placing brackets in the esthetic zone, as maxillary central incisors should appear more extruded than intruded in order to guarantee a youthful smile.
Another aspect that needs to be evaluated when modifying vertical position of the maxillary central incisors is the mandibular function. It is clear that extruding or intruding those teeth may influence mandibular lateral excursive and protrusive movements. Therefore, before making any vertical modification in maxillary centrals to optimize smile esthetics, the mandibular function should be carefully checked, and also, possible occlusal adjustments may be necessary. ${ }^{29}$

In this study, we surveyed orthodontists and layperson. The first group was selected because previous studies showed that they are the most sensitive group in detecting deviations from ideal. ${ }^{13-18,20,23}$ The latter was chosen because they are the primary consumers of dental services, instead of practitioners, who are providers of care. ${ }^{19}$ In general, our results indicated that for the most attractive smiles, both groups displayed no statistical difference $(p>0.05)$. However, for the assessments of the least attractive smiles, orthodontists were more critical in their evaluation..$^{25,29}$ It can be hypothesized that an ideal smile arrangement can easily be recognized by any group of raters, but when deviations are included, they start to show differences in their judgment.

In previous studies, the smiles used for evaluation were from White female patients. ${ }^{14-16,19-21,25,29}$ For this reason, we followed others authors suggestion to include a smile from an Afro-American woman. ${ }^{20,23,25}$ The main reason for evaluating this smile was to survey possible differences in the influence of several vertical positions of maxillary centrals in the esthetic perceptions. The results of our study suggest that the behaviors of orthodontists and layperson were similar when the smiles of the White and Afro-American women were compared. Although the objective was not to compare those types of smiles, it can be stated that smile perception in both situations was similar.

When evaluating the full-face view compared with the close-up view of the smile, no significant difference $(p>0.05)$ was found in the majority of the situations. These findings agree with studies by other authors. ${ }^{16,20,23,31}$ In this way, it can be hypothesized that other components of the face, such as eyes, nose, and hair do not significantly influence the assessment of smile esthetics. On the other hand, this result differs from the study of Flores-Mir et al, ${ }^{32}$ who found different perceptions when layperson assessed facial photographs in comparison with close-up views, such as intraoral frontal photographs. 
Finally, it is important to remember that, since this study used computer manipulated smile images from two female patients, and the opinion of specific groups of individuals, the results should be carefully analyzed. As stated by Kokich et al, ${ }^{15}$ since the results and conclusions are based on averages, it is difficult to customize this information to a patient due to the subjectivity in evaluating smile esthetics. In addition, maxillary central incisor positioning is influenced by many variables, including age, sex, tooth anatomy, maxillary and lower design, etc. Therefore, the ideas proposed in this study should be carefully discussed with patients before deciding upon the most attractive central incisors vertical position for a given patient.

\section{CONCLUSIONS}

The outcomes of this study demonstrate the following:

1. The highest rated smiles showed two notable characteristics: a) the central incisor gingival margins matched the canine or were $0.5 \mathrm{~mm}$ below the line of the canine gingival margins; b) the central-tolateral incisal step was 1.0 to $1.5 \mathrm{~mm}$.

2. The least attractive smiles showed two notable characteristics: a) the central incisor gingival margins $1.0 \mathrm{~mm}$ above or $1.5 \mathrm{~mm}$ below the canine gingival margins; and b) no step between the centrals and laterals or a $2.5-\mathrm{mm}$ step.

3 . In general, for the most attractive smiles, orthodontists and layperson displayed no statistical difference $(p>0.05)$. However, for the assessments of the least attractive smiles, orthodontists were more critical in their evaluation $(p<0.05)$.

4. In general, no statistically significant difference $(p>0.05)$ was found between the full-face and close-up assessments of the smiles. 


\section{REFERENCES}

1. Lombardi RE. The principles of visual perception and their clinical application to denture esthetics. J Prosthet Dent. 1973 Apr:29(4):358-82

2. Tjan AH, Miller GD, The JG. Some esthetic factors in a smile. J Prosthet Dent. 1984 Jan;51(1):24-8.

3. Rufenacht CR. Fundamentals of esthetics. Chicago: Quintessence; 1990

4. Peck S, Peck L. Selected aspects of the art and science of facial esthetics. Semin Orthod. 1995 June;1(2):105-26.

5. Machado AW. 10 commandments of smile esthetics. Dental Press J Orthod. 2014 July-Ago;19(4):136-57.

6. Chiche G, Pinault A. Esthetics of anterior fixed prosthodontics. Chicago: Quintessence; 1994

7. Camara CA. Aesthetics in Orthodontics: six horizontal smile lines. Dental Press J Orthod. 2010;15(1):118-31.

8. Sarver DM, Ackerman MB. Dynamic smile visualization and quantification Part 2. Smile analysis and treatment strategies. Am J Orthod Dentofacial Orthop. 2003 Aug;124(2):116-27.

9. Sarver DM, Ackerman JL. Orthodontics about face: the re-emergence of the esthetic paradigm. Am J Orthod Dentofacial Orthop. 2000 May:117(5):575-6

10. Van der Geld P, Oosterveld P. Heck GV, Kuijpers-Jagtman AM. Smile attractiveness: self-perception and Influence on Personality. Angle Orthod. 2007 Sept;77(5):759-65

11. Ioi H, Kang S, Shimomura T, Kim SS, Park SB, Son WS, et al. Effects of vertical positions of anterior teeth on smile esthetics in Japanese and korean orthodontists and orthodontic patients. J Esthet Restor Dent. 2013 Aug:25(4):274-82.

12. Owens EG, Goodacre CJ, Loh PL, Hanke G, Okamura M, Jo KH, et al. Multicenter Interracial Study of Facial Appearance. Part 2: A Comparison of Intraoral Parameters. Int J Prosthodont. 2002;15(3):283-8.

13. Parekh SM, Fields HW, Beck M, Rosenstiel S. Attractiveness of variations in the smile arc and buccal corridor space as judged by orthodontists and laymen. Angle Orthod. 2006 July:76(4):557-63.

14. Kokich VO, Kiyak HA, Shapiro PA. Comparing the perception of dentists and lay people to altered dental esthetics. J Esthet Dent. 1999;11(6):31124

15. Kokich VO, Kokich VG, Kiyak HA. Perceptions of dental professionals and laypersons to altered dental esthetics: asymmetric and symmetric situations. Am J Orthod Dentofacial Orthop. 2006 Aug:130(2):141-51.

16. Correa BD, Bittencourt MAV, Machado AW. Influence of maxillary canine gingival margin asymmetries on the perception of smile esthetics among orthodontists and laypersons. Am J Orthod Dentofacial Orthop. 2014 Jan;145(1):55-63.

17. Wolfart S, Thormann H, Freitag S, Kern M. Assessment of dental appearance following changes in incisor proportions. Eur J Oral Sci. 2005:113(2):159-65
18. Bukhary SM, Gill DS, Tredwin CJ, Moles DR. The influence of varying maxillary lateral incisor dimensions on perceived smile esthetics. $\mathrm{Br}$ Dent J. 2007:203(12):687-93

19. Ker AJ, Chan R, Fields HW, Beck M, Rosenstiel S. Esthetics and smile characteristics from the layperson's perspective: a computer-based survey study. J Am Dent Assoc. 2008;139(10):1318-27.

20. Nascimento DC, Santos ER, Machado AWL, Bittencourt MAV. Influence of buccal corridor dimension on smile esthetics. Dent Press J Orthod 2012:17(5):145-50.

21. Machado AW, Moon W, Campos E, Gandini LG. Influence of spacing in the upper lateral incisor area on the perception of smile esthetics among orthodontists and laypersons. J World Fed Orthod. 2013 Dec;2(4):169-74

22. Gul-e-Rum, Fida M. Changes in smile parameters as perceived by orthodontists, dentists, artists, and layperson. World J Orthod. 2008 Summer;9(2):132-40.

23. Suzuki L, Machado AW, Bittencourt MAV. An evaluation of the influence of gingival display level in the smile esthetics. Dental Press J Orthod. 2011:16(5):37-9.

24. Rosenstiel SF, Rashid RG. Public preferences for anterior tooth variations a web-based study. J Esthet Restor Dent. 2002;14(2):97-106.

25. Machado AW, Moon W, Gandini LG. Influence of maxillary incisor edge asymmetries on the perception of smile esthetics among orthodontists and laypersons. Am J Orthod Dentofacial Orthop. 2013 May;143(5):65864

26. Cao L, Zhang K, Bai D, Jing Y, Tian Y, Guo Y. Effect of maxillary incisor labiolingual inclination and anteroposterior position on smiling profile esthetics. Angle Orthod. 2011 Jan;81(1):121-9.

27. King KL, Evans CA, Viana G, BeGole E, Obrez A. Preferences for vertical position of the maxillary lateral incisors. World J Orthod. 2008 Summer:9(2):147-54

28. Vig RG, Brundo GC. The kinetics of anterior tooth display. J Prosthet Dent. 1978:39(5):502-4.

29. Machado AW, McComb RW, Moon W, Gandini LG. Influence of the vertical position of maxillary central incisors on the perception of smile esthetics among orthodontists and laypersons. J Esthet Restor Dent. 2013 Dec;25(6):392-401

30. Charruel S, Perez C, Foti B, Campos J, Monnet-Corti V. Gingival contour assessment: clinical parameters useful for esthetic diagnosis and treatment. J Periodontol. 2008:79(5):795-801.

31. Caramello F, Bittencourt MAV, Machado AW. Influence of maxillary incisor level of exposure on the perception of dentofacial esthetics among orthodontists and laypersons. J World Fed Orthod. 2015:4(3):108-13.

32. Flores-Mir C, Silva E, Barriga MI, Lagravère MO, Major PW. Lay person's perception of smile esthetics in dental and facial views. J Orthod. 2004:31(3):204-9 